\title{
Battle for Sex?: Protecting Sexual(ity) Rights in Africa
}

\author{
Dan Kuwali*
}

\begin{abstract}
Most African states see permission of unconventional sexuality and recognition of same-sex marriages as "deviant" in relation to the traditional sex roles of women and men. States have invoked justifications such as "cultural sovereignty," "protection of public morals," "religious sanctity," and "traditional values" as a rationalization for criminalizing queer sexuality. However, religious leadership, not the state, has the responsibility to guide the morality of individuals. Everyone should enjoy equal rights irrespective of their sexuality, including sexual orientation and sexual identity. The realization of the rights of "all people born free and equal in dignity" will require criminalizing homophobia, not homosexuality.
\end{abstract}

\section{INTRODUCTION}

Although sexual orientation is a relatively recent notion in human rights law and practice, it is certainly one of the most controversial political topics. ${ }^{1}$ In Africa, the debate is acrimonious and the opposition strong due to socially conservative cultural and religious traditions. ${ }^{2}$ Asserting sexual orientation as

\footnotetext{
* Dan Kuwali Post-Doctoral Fellow, Centre for Human Rights, Faculty of Law, University Pretoria; Fellow, Carr Center for Human Rights Policy, Harvard Kennedy School of Government, Harvard University; and Associate Professor, Centre for Security Studies, Mzuzu University. This piece is dedicated to my mentor and friend, Professor Frans Viljoen, for his genuine commitment to, and unwavering support for, furthering the cause of human rights education and human rights realization in Africa.

1. Human Rights Education Association (HREA), Sexual Orientation and Human Rights, available at http://www.hrea.org/index.php?doc_id=432.

2. Makau Mutua, Sexual Orientation and Human Rights: Putting Homophobia On Trial, in African Sexualities: A Reader 452, 452 (Sylvia Tamale ed., 2011).
} 
a universal right is a culturally divisive and polarizing issue and, therefore, unlikely to achieve consensus in human rights circles. ${ }^{3}$ However, the debate today is no longer whether (homo)sexuality is a human rights issue, but rather how to respect and protect sexuality rights, particularly equal protection and non-discrimination on the grounds of sexual orientation and sexual identity, as well as legal recognition of same-sex marriages. ${ }^{4}$

Without a claw back clause, Article 2 of the African Charter of Human and Peoples' Rights (Banjul Charter) prohibits any form of discrimination by guaranteeing that:

Every individual shall be entitled to the enjoyment of the rights and freedoms recognized and guaranteed in the present Charter without distinction of any kind such as race, ethnic group, colour, sex, language, religion, political or any other opinion, national and social origin, fortune, birth or other status. ${ }^{5}$

Also, Article 3 of the Banjul Charter provides that "[e]very individual shall be equal before the law" and that "[e]very individual shall be entitled to equal protection of the law." ${ }^{6}$ The principle of non-discrimination in Article 2 and the principle of equality in Article 3 are mutually reinforcing so much so that "the latter may be said to be a positive expression of the former." ${ }^{\text {" }}$ Further, Article 19 guarantees that "[a]ll peoples shall be equal; they shall enjoy the same respect and shall have the same rights." ${ }^{8}$ Nothing shall justify the domination of a people by another. The African Commission of Human and Peoples' Rights has pointed out that the elimination of all forms of discrimination is a common objective of Article 2 of the Banjul Charter. ${ }^{9}$ Nonetheless, "differential treatment is not considered discrimination if the criteria for differentiation are 'reasonable and objective,' and if the aim is to achieve a purpose deemed 'legitimate' under international standards."10 However, in several cases, states have failed to provide justification for

3. See Ignacio Saiz, Bracketing Sexuality: Human Rights and Sexual Orientation-A Decade of Development and Denial at the UN, Sexuality Policy Watch, Working Papers No. 2, at 12-13 (2005).

4. Int'l Council on Human Rights Policy, Sexuality and Human Rights (2009), available at http:// www.ichrp.org/files/reports/47/137_web.pdf [hereinafter Sexuality and Human Rights].

5. African Charter on Human and Peoples' Rights, adopted 27 June 1981, O.A.U. Doc. CAB/LEG/67/3 Rev. 5, 1520 U.N.T.S. 217 (entered into force 21 Oct. 1986) [hereinafter Banjul Charter].

6. Id. art. 3 .

7. Fatsa Ouguergouz, The African Charter on Human and Peoples' Rights: A Compremensive Agenda for Human Dignity and Sustainable Democracy in Africa 77 (2003).

8. Banjul Charter, supra note 5, art. 19.

9. See, e.g., African Comm'n on Human and Peoples' Rights, Thirteenth Annual Activity Report of the African Commission on Human and People's Rights 1999-2000, at 159, ब 131, OAU Doc. AHG/222(XXXVI).

10. Saiz, supra note 3, at 18; Human Rights Comm. (HRC), General Comment 18, NonDiscrimination, ๆ 13 (1989). 
making distinctions on the basis of sexuality, including both sexual orientation and sexual identity. ${ }^{11}$

The more difficult issue, and the one addressed in this paper, is the justification for discrimination against sexual minorities and the concomitant criminalization of queer sexuality and infringement of, inter alia, the rights to privacy, freedom of expression, freedom of association, and family life. The primary aim of this paper is to clarify the essential elements of a policy discussion of sexuality rights from a human rights perspective and to outline how to confront conceptual and legal challenges faced in arguing for the universality of sexuality rights. ${ }^{12}$ The aim is to help define a framework for clearer thinking about sexuality rights in advocacy, research, and policy in this area. The goal is to change the attitude of legal and political elites towards queer sexuality, especially in Africa where homophobia is deeply embedded in the social fabric. ${ }^{13}$

The premise is that although perceptions of sexuality and gender are socially and culturally constructed, "all people have a sexual orientation and a gender identity and these are not factors that they can or should have to change." 14 Therefore, the debate should first break out of the binaries of heterosexuality and homosexuality and focus on the overarching concept of sexuality. The logic is analogous to the elimination of racism-which does not proscribe discrimination against blacks or whites, but rather encourages a broader understanding of color, race and status. The internal logic is based on equal protection and anti-discrimination. ${ }^{15}$ In this way, to achieve equality, laws should prohibit homophobia and not homosexuality. ${ }^{16}$ The discourse of sexuality rights offers fresh conceptual and strategic tools for framing the issue of sexuality from various perspectives including rights to dignity, privacy, family life, and freedom of choice, among others. ${ }^{17}$

11. See, e.g., Young v. Australia, HRC, Commc'n No. 941/2000: Australia, CCPR/ C/78/D/941/2000 (2003) (The HRC found that the denial of pension benefits to the same-sex partner of a deceased war veteran breached General Comment 18, as Australia had failed to provide any justification for making distinctions on the basis of "sex or sexual orientation."); see also Siaz, supra note 3, at 9.

12. Kees Waaldijk, Same-Sex Partnership, International Protection, in Max Plank Encyclopedia of Public International Law 92 (2012).

13. See Mutua, supra note 2, at 452; see also Saiz, supra note 3, at 15-16.

14. Amnesty Int'L, Love, Hate and the Law: Decriminalizing Homosexuality 8 (2008).

15. Mutua, supra note 2, at 455 .

16. Edward Stein, Law, Sexual Orientation, and Gender, in The Oxford Handbook of Jurisprudence and Philosophy of Law 990, 1007 (Jules Coleman \& Scott Shapiro eds., 2002).

17. The discourse of sexual rights also offers strategic possibilities for building coalitions or bridges between diverse movements so as to confront common obstacles more effectively and explore how different discourses of subordination work together. See Saiz, supra note 3 , at 8 . 


\section{SEXUALITY, EQUALITY, AND RECOGNITION}

\section{A. Homophobia or "Homosexuality"?}

It should be stated at the outset that, in this paper, the word homosexuality is avoided because of its negative connotations relating to the way it has been used in the past. Instead the terms "unconventional" or "queer" sexuality will be used interchangeably. ${ }^{18}$ Although the focus is on how to address homophobia in Africa, reference is made to jurisprudence from other continents because of the paucity of African scholarship and law on the subject.

Sexuality is the capacity to have erotic experiences and responses. ${ }^{19}$ Sexuality can also refer to the way someone is sexually attracted to another person (sexual orientation), ${ }^{20}$ whether it is to the opposite sex (heterosexuality), to the same sex (homosexuality), to either sex (bisexuality), to all gender identities (pansexuality), or not being attracted to anyone in a sexual manner (asexuality). ${ }^{21}$ This means that there are not only two sexual orientationsheterosexual and homosexual-as is the dominant social view, but also bisexual, asexual, transsexual, and queer. ${ }^{22}$ None of these sexual orientations are normal or abnormal because each is an existential condition. ${ }^{23}$ However, Carl Stychin has noted that:

The use of categories of prohibited discrimination in itself is problematic in the context of sexual orientation (as it is with other prohibited grounds). The approach gives rise to rigid binary classification-the norm (heterosexuality) and the exception (homosexuality) into which individuals can be "slotted." Such an approach is increasingly out of step with the current theory and practice of sexuality. ${ }^{24}$

Human sexuality impacts cultural, political, legal, and philosophical aspects of life. It can refer to issues of morality, ethics, theology, spirituality, or religion. Sexuality is not, however, directly linked to gender. Some forms of sexuality have been described as immoral, unnatural, or foreign.

18. See generally Aaron Xavier Fellmeth, State Regulation of Sexuality in International Human Rights Law and Theory, 50 WM. \& MARY L. Rev. 797, 825 (2008) (Mr. Fellmeth uses the term "unconventional sex.").

19. Farlex, (Definition of) Community Dictionary, Human Sexuality, available at http://www. definition-of.com/human\%20sexuality.

20. HREA, supra note 1.

21. University of California, Santa Barbara's SexInfo, available at http://www.soc.ucsb.edu/ sexinfo/.

22. Mutua, supra note 2 , at 457.

23. Id.

24. Carl. F. Stychin, Essential Rights and Contested Identities: Sexual Orientation and Equality Rights Jurisprudence in Canada, in Understanding Human Rights 223 (Conor Gearty \& Adam Tomkins eds., 1996). 
However, it is a misnomer to refer to any sexuality or sexual orientations as normal or abnormal because each is an existential condition, meaning that whatever sexual orientation one has is natural.

Radhika Coomaraswamy coined the term "sexual rights" and described them as a constellation of existing rights, including "the right to information, based upon which one can make informed decisions about sexuality; the rights to dignity, to privacy and to physical, mental and moral integrity in realizing a sexual choice; and the right to the highest standard of sexual health." 25 To describe such rights as sexual rights tends to limit the focus on sexual acts at the expense of non-sexual aspects of sexuality such as personhood, lifestyle, and family life. As the term sexual rights seems to be limited to that which is sexual, here the more expansive term "sexuality rights" will be employed.

The notion of sexuality rights is broader and commands a stronger claim to universality, as it constitutes an element of the self that is common to all human beings. "The concept, therefore, avoids the complex task of identifying a fixed sub-category of humanity to whom these rights apply." ${ }^{26}$ Sexuality rights present a positive claim of sexuality as a fundamental aspect of being human, which is central to the full development of the human personality and enjoyment of human rights, including freedom of conscience and protection of physical integrity. ${ }^{27}$ Sexuality rights need to focus on the broad spectrum of sexuality, including sexual conduct, sexual identity, relational status or orientation, and "participatory citizenship." ${ }^{28}$

More so, while sexuality is not directly tied to gender, it impacts cultural, political, legal, and philosophical aspects of life. The concept of sexuality rights is more expansive, as it addresses "the intersections between sexual orientation discrimination and other sexuality issues-such as restrictions on all sexual expression outside heterosexual marriage or abuses against sex workers-and to identify root causes of different forms of oppression." ${ }^{29}$

There is a problem of analytical confusion. For example, transgender persons are often referred to as "gay" in advocacy reports, even when transgender indicates a gender identification or presentation, not a direction of sexual orientation (attraction). ${ }^{30}$ Historically polarizing and culturally sensitive concepts such as "lesbian and gay" and "sexual minorities" have no pedigree of being "the kind of fixed universally applicable categorization

25. Radhika Coomaraswamy, Reinventing International Law: Women's Rights as Human Rights in the International Community, Edward A. Smith Visiting Lecture, Harvard Law School, 1997 cited in Saiz, supra note 3, at 19 n.102.

26. Saiz, supra note 3 , at 20 .

27. Id.

28. Sexuality and Human Rights, supra note 4, at 4; Diane Richardson, Constructing Sexual Citizenship: Theorizing Sexual Rights, 62 Critical Soc. Pol'y 105 (2000).

29. Saiz, supra note 3 , at 20.

30. Sexuality and Human Rights, supra note 4, at 19. 
that is necessary for codification in antidiscrimination instruments." ${ }^{31}$ The narrow morality that informs state regulation of sexuality contributes to the lack of coherent thinking about the rules that should govern state interference in sexual conduct. ${ }^{32}$

Despite the positive proliferation of principles in this area, there is no coherent human rights doctrine in this area. ${ }^{33}$ For instance, some sexuality rights-oriented declarations only focus on health. ${ }^{34}$ The Yogyakarta Principles rely primarily on a specific concept of sexual orientation and gender identity. ${ }^{35}$ Still other initiatives adopt a feminist analysis of patriarchy. ${ }^{36}$ These initiatives have different foci and priorities and speak to different, albeit sometimes overlapping constituencies. ${ }^{37}$ "Divisions are exacerbated by confusion over what sexuality entails, and whether rights should or do address conduct, identities, relationships, sexual expression, individuals or groups; or when a problem is about sexuality or gender and how these aspects interact." ${ }^{\prime 38}$

It is difficult to decide which policies on sexuality should be supported or opposed in the absence of clarity on these issues. Agreement regarding key principles of sexuality rights may be futile in the absence of a coherent and intelligent body of thought about sexuality. ${ }^{39}$ Given that there is powerful opposition to sexuality rights globally, more coherence is keenly needed. Any effort to clarify and deepen conceptual understanding of sexuality rights as human rights is a deeply political project. It is political both because of the importance and sensitivity of sexuality and sexual issues and because

31. Saiz, supra note 3 , at 18 .

32. Sexuality and Human Rights, supra note 4, at 22.

33. Sexuality and Human Rights, supra note 4, at 20 (The proliferation of acronyms-GBV (gender based violence), SOGI (sexual orientation and gender identity), and SRHR (sexual and reproductive health rights) — has begun to obscure the common roots of oppression for each of the named groups).

34. Int'I Planned Parenthood Federation, Sexual Rights: An IPPF Declaration (2008), available at http://ippf.org/sites/default/files/sexualrightsippfdeclaration_1.pdf. (This is a feminist-led initiative.)

35. The Yogyakarta Principles on the Application of International Human Rights Law in relation to Sexual Orientation and Gender Identity, available at http://www.yogyakartaprinciples. org [hereinafter Yogyakarta Principles] ("The Principles are intended as a coherent and comprehensive identification of the obligation of States to respect, protect, and fulfill the human rights of all persons regardless of their sexual orientation or gender identity."); see also Michael O'Flaherty \& John Fisher, Sexual Orientation, Gender Identity and International Human Rights Law: Contextualising the Yogyakarta Principles, 8 Hum. RTs. Rev. 207, 207 (2008).

36. For example, The Campaign for a Convention on Sexual and Reproductive Rights (The Latin American and Caribbean Committee for the Defense of Women's Rights, (CLADEM). See Int'I Women's Health Coalition, Campaign for an Inter-American Convention on Sexual and Reproductive Rights, available at http://www.iwhc.org/index.php?option=com_con tent\&task=view\&id=205\&Itemid=110; see also AMNESTY INT'L, supra note 14, at 11.

37. AMNESTY INT'L, supra note 14 , at 12 .

38. Sexuality and Human Rights, supra note 4, at 4.

39. Gayle Rubin, Thinking Sex: Notes for a Radical Theory of the Politics of Sexuality, in Pleasure and Danger: Exploring Female Sexuality 267, 267 (Carole S. Vance ed., 1984). 
it seems to reconfigure the relationship between individuals and the state. ${ }^{40}$ The problem is not homosexuality, but rather homophobia in the sense of discrimination on the basis of sexuality. ${ }^{41}$ The stigmatization is not only on queer acts but also the very existence of the person. It should be understood that individuals practicing queer sex does not prohibit them from being entitled to the full enjoyment of human rights. ${ }^{42}$

\section{B. (Homo)Sexuality and Universality of Human Rights}

In Schalk and Kopf v. Austria, the applicants were two men living in a stable and committed same-sex partnership. ${ }^{43}$ Their marriage request was refused by the Austrian authorities on the ground that marriage could only be contracted between two persons of the opposite sex. The Austrian courts upheld this view. ${ }^{44}$ When the matter went before the European Court of Human Rights (ECtHR), the Court held that it could not oblige a member state to legislate or legally recognize same-sex marriages because national authorities were best placed to assess and respond to the needs of society in regard to family life, especially marriage, which has deeply-rooted social and cultural connotations differing greatly from one society to another. ${ }^{45}$ The ECtHR found that there was no violation of the provisions of the European Convention on Human Rights, particularly Article 12 (right to marry and found a family) and Article 14 (prohibition of discrimination) as read with Article 8 (right to respect for private and family life). ${ }^{46}$ The dissenting opinion in this case contended that because the differences based on sexual orientation required cogent justification, the Court should have found a violation of Article 14 in conjunction with Article 8 of the ECHR because Austria did not advance any argument to justify the difference of treatment and there should be no room to apply the margin of appreciation. ${ }^{47}$

While the judgment of the ECtHR in Schalk and Kopf v. Austria hinges on the doctrine of margin of appreciation, an ECtHR doctrine that grants leeway to state political machinations in interpreting and implementing the $\mathrm{ECHR}^{48}$ it also borders on cultural relativism of human rights application. The question of universality of human rights was settled in 1993 when it was

40. See Jenny A. Higgins, Susie Hoffman \& Shari L. Dworkin, Rethinking Gender, Heterosexual Men, and Women's Vulnerability to HIVIAIDS, 100 Aм. J. Pub. Health 435 (2010).

41. See Lawrence v. Texas, 539 U.S. 558, 594 (2003).

42. Mutua, supra note 2, at 453.

43. Schalk and Kopf v. Austria, App. No. 30141/04, Eur. Ct. H.R., I 7 (2010).

44. Id. I 9.

45. Id. ศ 13

46. Id.

47. Id. I 8, joint dissent of Judges Rozakis, Jebens, and Tulkens.

48. Handyside v United Kingdom, App. No. 5493/72, 1 Eur. H.R. Rep. 737, ๆ 48-49 (1976). 
declared that "[a]II human rights are universal, indivisible and interdependent and interrelated." ${ }^{49}$ The Vienna Declaration and Programme of Action (VDPA) stated that "[w]hile the significance of national and regional particularities and various historical, cultural and religious backgrounds must be borne in mind, it is the duty of States, regardless of their political, economic and cultural systems, to promote and protect all human rights and fundamental freedoms." ${ }^{\prime 50}$ It should be noted that the principle of universality of human rights does not mean uniformity in the application of human rights globally, as human rights will manifest themselves in a variety of forms across global cultures. ${ }^{51}$ Viljoen is of the view that:

The principle of universality of human rights does not . . . mean uniformity in the application of this principle across the globe . . human rights will manifest themselves in a variety of forms across . . . . However, cultural-specific manifestations-or manipulations thereof-fly in the face of an evolving common sense of humanity on what dignity entails if these interpretations support oppression. . . Ideally, human rights should not be enforced or imposed, but should be part of a process of dialogue about how universal values may best be integrated into local contexts. ${ }^{52}$

The VDPA reconciled the competing claims of cultural relativism and universal human rights by asserting that the Universal Declaration of Human Rights (UDHR) "constitutes a common standard of achievement for all peoples and all nations." 53 This view is buttressed by Donnelly, who maintains that:

Despite striking and profound international differences in ideology, levels and styles of economic development, and patterns of political evolution, virtually all states today have embraced - in speech if not in deed - the human rights standards enunciated in the Universal Declaration of Human Rights and the International Human Rights Covenants. This consensus presents a strong prima facie case for a relatively strong universalism; that is; for weak cultural relativism. Even if this "consensus" is largely the complement of vice to virtue, it reveals widely shared notions of "virtue," an underlying "universal" moral position compelling at least the appearance of assent from even the cynical and corrupt. ${ }^{54}$

49. Vienna Declaration and Programme of Action, adopted 25 June 1993, U.N. GAOR, World Conf. on Hum. Rts., 48th Sess., 22d plen. mtg., Pt. 1, I 5, U.N. Doc. A/CONF.157/23 (1993), reprinted in 32 I.L.M. 1661 (1993) [hereinafter Vienna Declaration].

50. Id. I 3.

51. Frans Viljoen, International Human Rights Law in Africa 8 (2d ed. 2011).

52. Id.

53. SeeVienna Declaration, supra note 49, pmbl.; see also Universal Declaration of Human Rights, G.A. Res. 217 (III) A, pmbl., U.N. Doc. A/RES/217(III) (10 Dec. 1948) [hereinafter UDHR].

54. Jack Donnelly, Cultural Relativism and Universal Human Rights, 6 Hum. RTs. Q. 400, 414 (1984). 
Actually, Viljoen has noted that "[a]II African states also now subscribe to human rights by including them-in one form or another-in their domestic constitutional orders." ${ }^{55}$ Further, Donnelly argues that:

If human rights are based in human nature, on the simple fact that one is a human being, and if human nature is universal, then how can human rights be relative in any fundamental way? The simple answer is that human nature is itself in some measure culturally relative. . . . But if all rights rested solely on culturally determined social rules ... then there could be no human rights, no rights one has simply as a human being. ${ }^{56}$

To this end, the UDHR provides that "[a]Il human beings are born free and equal in dignity and rights." ${ }^{57}$ Human rights are a "birth right of all human beings" and are fundamental to humankind itself. ${ }^{58}$ The UDHR also dictates that "[e]veryone is entitled to all the rights and freedoms set forth in this Declaration, without distinction of any kind, such as race, colour, sex, language, religion, political or other opinion, national or social origin, property, birth or other status." 59 This notwithstanding, discrimination against people indulging in unconventional sexual practices —also known as sexual minorities or lesbian, gay, bi-sexual, and transgender (LGBT) people or persons-has international dimensions. ${ }^{60}$ As stated earlier, discrimination against LGBT is so prevalent in Africa owing to the socially conservative cultural and religious traditions. ${ }^{61}$

It may seem to be reasonable to state that LGBT rights should not be enforced or imposed on Africans. However, as it will be discussed in detail below, LGBT people do not demand any special or additional rights, but simply protection and recognition of the same rights as those of heterosexual persons. ${ }^{62}$ The issue, therefore, is to engage in a conversation on how universal values may best be understood and integrated into African contexts. ${ }^{63}$ In addition to the principles of non-discrimination and equality in Articles 2 and 3, Article 28 of the Banjul Charter can be read in a manner that furthers LGBT rights, as it proscribes discrimination in inter-personal relations. ${ }^{64}$ That provision stipulates that "[e]very individual shall have the duty to respect and

55. VILJOEN, supra note 51, at 7.

56. Donnelly, supra note 54, at 403-04.

57. UDHR, supra note 53, art. 1.

58. Vienna Declaration, supra note 49 , art. 1, ๆ 1.

59. UDHR, supra note 53, art. 2.

60. Ajnesh Prasad, Jack Donnelly's Universal Human Rights Theory and Practice, 3 Turk. J. INT'L REL. 4 (2004), available at http://www.alternativesjournal.net/volume3/number2/ ajnesh.pdf.

61. Mutua, supra note 2 , at 452 .

62. Id.

63. ViLjOEN, supra note 51 , at 8.

64. See Fatsa Ouguergouz, The African Charter on Human and Peoples' Rights: A Comprehensive Agenda for Human Dignity and Sustainable Democracy in Africa 86 (2003). 
consider his fellow beings without discrimination, and to maintain relations aimed at promoting, safeguarding and reinforcing mutual respect and tolerance." It can be argued, therefore, that safeguarding and reinforcing mutual respect and tolerance suggests, necessarily, respecting and tolerating difference that is premised on sexuality, including sexual orientation and sexual identity. Considering that Africans have been prominent proponents of the protection of equal rights and nondiscrimination, it would be paradoxical for them to discriminate against LGBT people.

\section{ARE THERE SEXUALITY RIGHTS?}

There is a paucity of international legal authority affirming the existence of sexuality rights as a category of rights. ${ }^{65}$ "Both historically and today, almost all sexual behaviour has to be justified: traditionally, by reference to marriage, reproduction; today, by love." 66 LGBT persons are denied-either by law or social practices-basic civil, political, social, and economic rights on the basis of their sexuality. In proclaiming sexuality rights, LGBT persons and advocates do not claim any special or additional rights but the observance of the same rights as those of heterosexual persons. ${ }^{67}$ The same applies to other gender identities, i.e., pansexual, asexual, and transgender persons. Claims for sexuality rights can be grouped into three categories: claims for the decriminalization of same-sex sexual activity; claims for the protection against discrimination on the basis of sexual orientation; and claims for the recognition of same-sex relationships and institutions. ${ }^{68}$ These can further be condensed into two main claims: "non-discrimination or equality-based arguments" and "privacy-based arguments." ${ }^{19}$

States have generally objected to requests by sexual minorities to receive the same state-supported benefits that are provided freely to heterosexuals, such as marriage and parental rights. ${ }^{70}$ Some have argued that "sexual orientation, an 'undefined term,' may be a legitimate basis for discrimination to protect children and the family." that sexual orientation is "a 'non-subject' that would open the floodgates to unacceptable behavior." ${ }^{\prime 2}$ States have tried to invoke several exceptions in human rights instruments to justify discrimination against sexual minorities or queer sexuality. ${ }^{73}$

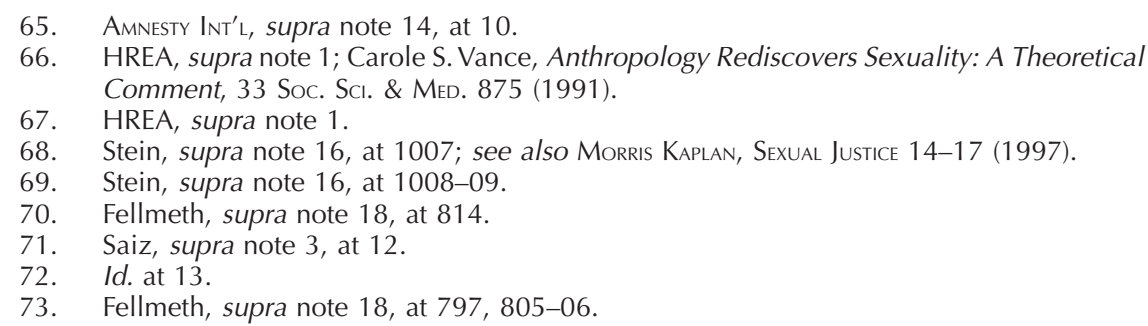


However, "the most difficult forms of regulation to justify are criminal prohibitions on unconventional sexual behavior, as these entail the most intrusive form of state regulation into the most private and personal of behaviors." ${ }^{174}$ It is contended that sexual orientation is either inborn or fixed at an early age. ${ }^{75}$ It is argued that "if people do not choose to be lesbian, gay, or bisexual, it is wrong to criminalize their sexual behaviour, discriminate against them, and withhold from them benefits that heterosexuals take for granted." ${ }^{176}$ Where laws that criminalize same-sex sexual activities have been repealed, laws that discriminate on the basis of sexuality are enacted-a case of playing musical chairs.

Regardless of whether sexuality is chosen or not, sexual minorities "deserve protection against discrimination and recognition for their relationships and institutions with respect to their actions and decisions rather than for their mere orientations. It is when they engage in same-sex acts, identify as gay men and lesbians, and create lesbian and gay families that they especially need" protection. ${ }^{77}$ This explains the indirect discrimination posed by the now repealed "Don't Ask, Don't Tell" policy in the US military. ${ }^{78}$

The "Don't Ask, Don't Tell" policy was meant to protect sexual minorities in the US military from discrimination on the basis of their sexual orientation (same-sex). However, a person could be "discharged for any public expression of homosexuality, any evidence of romantic relationships with people of the same sex, and any form of remotely intimate physical contact with people of the same sex." ${ }^{\prime \prime 9}$ As a result, the policy could not, in fact, proactively protect those service members who had queer sexuality. The "Don't Ask, Don't Tell" paradigm exemplifies policies or laws that are likely to be implemented in the face of "born that way" argument-that is to say, laws that purport to protect people for the mere having of sexual orientation but not any behavior that might result from such desires. ${ }^{80}$ This strengthens the need to focus on the broader spectrum of sexuality rather than confine sexuality to the concepts of sexual orientation and sexual identity; especially considering that every individual is equal before the law and is entitled to equal protection in terms of Article 3 of the Banjul Charter. ${ }^{81}$ Going by the obligation under Article 28 of the Banjul Charter, there is a duty to respect and consider one another without discrimination even on the basis of

74. Id. at 814 .

75. Stein, supra note 16, at 1011 (As stated by researchers, citing evidence from neurology, genetics, and psychology); see also KAPLAN, supra note 68.

76. Stein, supra note 16 , at 1011.

77. Id. at 1013 .

78. Id. at 1013-14.

79. Id. at 1014 .

80. Id. at 1013-14.

81. Banjul Charter, supra note 5, art. 3 . 
sexuality "and to maintain relations aimed at promoting, safeguarding and reinforcing mutual respect and tolerance." ${ }^{82}$ Article 3 of the Banjul Charter provides that "[e]very individual shall be equal before the law" and that "[e] very individual shall be entitled to equal protection of the law." 83

\section{HOSTILITY AGAINST (HOMO)SEXUALITY}

Hostility against (homo)sexuality remains a barrier to achieving the universality of human rights, including sexuality rights. Governments have erected shields of "cultural and national sovereignty to evade their internationally recognized rights obligations." ${ }^{84}$ Governments, especially in Africa, have invoked justifications such as "cultural sovereignty," "protection of public morals," "religious sanctity," and "traditional values" as a justification for denying liberalization of unconventional sexuality, including sexual orientation..$^{85}$

\section{A. The Adam and (St)Eve Argument}

To a large extent, the condemnation of queer sexuality has been shaped by religious and moral beliefs, including conceptions of "right," "natural," and "acceptable" behavior, and respect for the traditional family. Many people consider queer sexuality as a deviation from their accepted ethical and moral principles, which determine the course of their lives. In many parts of the world, queer sexuality is considered a sin and same-sex relations are perceived as "unChristian" or "unlslamic." Many of the criminalization laws dating back to the Victorian period of the British Empire derive from Christian religious law, premised on Biblical notions of the sin of Sodom and Gomorrah. ${ }^{86}$ Some have even argued that God created Adam and Eve-not Steve-and that homosexuality is a dirty sin and, therefore, a crime. ${ }^{87}$ But Mutua has revealed an interesting point:

There is no unanimity among religions about homosexuality. Not all religions believe that God hates gays or adopt the view that homosexuality is a sin. Some American First Nation traditions venerated homosexuality and, in the United

82. Id. art. 28.

83. Id. art. 3.

84. Saiz, supra note 3 , at 15 .

85. Id. at 15 .

86. Amnesty Int'L, supra note 14, at 14; Arvind Narrain, Queer: "Despised Sexuality," Law, and Social Change 49-55 (2005); Sumit Baudh, Human Rights and the Criminalization of Consensual Same-Sex Sexual Acts in the Commonwealth, South and Southeast Asia, The South and Southeast Asia Resource Centre on Sexuality, Working Paper 4 (2008).

87. J.J Sonke, Decriminalize Homosexuality, The NAtıon (Malawi), 4 Nov. 2011, at 16. 
Kingdom, the Hindu council has taken the view that it does not condemn homosexuality. ${ }^{88}$

In the Fiji case of McCoskar v. The State, Judge Winter noted that "while members of the public who regard homosexuality as amoral may be shocked, offended or disturbed by private homosexual acts, this cannot on its own validate unconstitutional law." ${ }^{89}$ Also, in finding the Pennsylvania prohibition on "deviate sexual intercourse" unconstitutional, the state Supreme Court reasoned that:

With respect to regulation of morals, the police power should properly be exercised to protect each individual's right to be free from interference in defining and pursuing his own morality but not to enforce a majority morality on persons whose conduct does not harm others [. . . M Many issues that are considered to be matters of morals are subject to debate, and no sufficient state interest justifies legislation of norms simply because a particular belief is followed by a number of people [. . .] Spiritual leadership, not the government, has the responsibility for striving to improve the morality of individuals..$^{90}$

In defending the proposal for same-sex marriages, the Home Office in the United Kingdom has argued that religious bodies would not and cannot be forced to solemnize same-sex marriages. ${ }^{91}$ However, the Church of England contended that the role of the Anglican clergy to perform marriages for parishioners would be compromised, thereby undermining the Church of England's role as the state church. ${ }^{92}$ From a human rights perspective, however, the issue of sexuality rights is not confined to the code of the Church, but it is entrenched in the bill of rights of democratic constitutions. ${ }^{93}$ This view is buttressed by the case of Lawrence $v$. Texas, where the US Supreme Court stated that the Court's "obligation is to define the liberty of all, not to mandate its own moral code." ${ }^{\prime 94}$

Similarly, in Smith and Grady v. United Kingdom, with specific reference to the human rights of LGBT people, the ECtHR declared that predisposed bias on the part of a heterosexual majority against a homosexual minority cannot, of itself, amount to sufficient justification for the interferences with

88. Mutua, supra note 2, at 459 (footnotes omitted).

89. McCoskar v. The State [2005] FJHC 500, HAA0085, 86 (Fiji), available at http://www. paclii.org/fj/cases/FJHC/2005/500.html.

90. Commonwealth v. Bonadio, 415 A.2d 47, 50 (Pa. 1980).

91. Church of England Warning on Gay Marriage, BBC News, 12 June 2012, available at http://www.bbc.co.uk/news/uk-18405318.

92. Id.

93. Per José Pallais, President of the Nicaraguan Parliament's Commission of Justice and Legal Issues, Nicaragua: Sodomy Statute Disappears From the Books (14 Nov. 2007), available at http://blabbeando.blogspot.com/2007/11/nicaragua-sodomy-statute-disappears.html.

94. Lawrence, supra note 41, at 571 (quoting Planned Parenthood of Southeastern Pa. v. Casey, 505 U. S. 833, 850 (1992)). 
the applicants' rights, including their right to sexual identity. ${ }^{95}$ To the extent that homophobic laws represent a predisposed bias of a heterosexual majority against a homosexual minority, such prejudice cannot, by itself, be sufficient justification. ${ }^{96}$ The decision in Commonwealth $v$. Bonadio held that issues of morality of individuals are the domain of religious leadership, whereas the responsibility of the government is to protect the rights of the citizenry. ${ }^{97}$

\section{B. Foreign Culture Justification}

Several governments, particularly in Africa, Asia, and the Middle East have "sought to bolster their domestic authority through nationalist rhetoric, portraying homosexuality as a foreign imposition and a manifestation of western decadence." ${ }^{98}$ Some states have criticized the "donor" communities that have threatened to withhold aid in order to persuade developing countries to decriminalize homosexuality. ${ }^{99}$ Others have maintained that the issue of homosexuality "is not a human rights issue but a social and cultural one, best left to each state to address within its own sovereign legal and social systems." 100 It has, however, been argued that it is historically false to say that homosexuality is un-African because there is evidence that gays have always been part of the social fabric in Africa. ${ }^{101}$ "It seems that in pre-colonial, pre-Christian, pre-Islamic Africa something akin to a policy of 'don't ask don't tell' might have prevailed." 102

Although laws proscribing homosexuality are defended in the name of preserving local cultural values or deterring the "foreign import" of homosexuality, such laws in many former colonies are in fact a legacy of the colonial past, where "the very identity and authority of the colonial project rested upon the racialization and sexualization of morality." ${ }^{103}$ Mutua explains that "homophobia is not necessarily home-grown in Africa because "much of the revulsion of homosexuality can be traced to Christianity and Islam," which are imported religions that express homophobia in their doctrines. ${ }^{104}$

95. Smith and Grady v. United Kingdom, App. Nos. 33985/96 \& 33986/96, 29 Eur. H.R. Rep. 493, I 97 (1999).

96. Lustig-Prean \& Beckett v. United Kingdom, App. Nos. 31417/96 \& 32377/96, 29 Eur. H.R. Rep. 548, ๆ 90 (1999).

97. Bonadio, supra note 90.

98. Saiz, supra note 3 , at 16 .

99. Sonke, supra note 87 , at 16 .

100. Saiz, supra note 3 , at 12 .

101. Mutua, supra note 2, at 459-60.

102. Id. at 460 .

103. M. Jacqui Alexander, Redrafting Morality: The Postcolonial State and the Sexual Offences Bill of Trinidad and Tobago, in ThiRd World Women and the Politics of Feminism 133, 133 (Chandra Talpade Mohanty, Ann Russo \& Lourdes Torres eds., 1991); AMNESTY INT'L, supra note 14 , at 27.

104. Mutua, supra note 2, at 452 . 
The public space for discussion of sexual speech, dress, and sexual comportment has been compromised by the influence of Victorian morality and the values it exported to former colonies. ${ }^{105}$

"The idea that sexual orientation is a characteristic that defines a person may make no sense to people who have different cultural systems of naming sexual practices and different ways of linking up sexual acts, reproduction, status and identity." ${ }^{106}$ In spite of the Vienna Declaration and Program of Action dictating that national and regional cultural and religious values cannot override fundamental human rights, states are still afforded a wide margin of discretion when it comes to matters of sexuality. ${ }^{107}$ However, as discussed above, all human beings are protected by universal norms of human rights and values in their basic identities and human conditions. ${ }^{108}$ To this end, the Banjul Charter prohibits discrimination in any other form in Article 2 and dictates that every person is equal before the law and entitled to equal protection under Article 3. Further, Article 28 of the Banjul Charter prohibits discrimination based on interpersonal relationships and obliges tolerance and mutual respect among individuals.

\section{In the Best Interest of the Children: Regulating Sexuality}

One other justification for criminalizing homosexuality has been under the pretext of the protection of children. One example is the recently repealed Austrian law, which was ostensibly designed to protect "a young, maturing person from developing sexually in the wrong way."109 "It becomes a selfpropagating system, with the negative emphasis on (homo)sexuality providing the justification for discrimination and persecution of LGBT persons by positioning them as a sexual threat to children."110 However, expert evidence shows that sexuality, particularly sexual orientation, is a human development occurring prior to or during adolescence. ${ }^{111}$

Many countries also maintain unequal ages of consent for young gay men and lesbians compared to the age of consent for heterosexual teenagers. ${ }^{112}$ Discriminatory age of consent laws criminalize the sexuality of lesbian and gay youths and hinder their access to sexual health information. ${ }^{113}$ The

105. Sexuality and Human Rights, supra note 4, at 37.

106. Id. at 18.

107. Id.; Vienna Declaration, supra note 49

108. Mutua, supra note 2, at 454.

109. Wolfmeyer v. Austria, App. No. 5263/03, 42 Eur. H.R. Rep. 3, I 21(2006); L. \& V. v. Austria, App. Nos. 39392/98 \& 39829/98, 36 Eur. H.R. Rep. 55, ๆ 24 (2003).

110. AMNESTY INT'L, supra note 14 , at 8.

111. See, e.g., Sutherland v. United Kingdom, App. No. 25186/94, 24 Eur. H.R. Rep. 22 (1997).

112. See AMnESTY INT'L, supra note 14 , at 20, n. 77.

113. See, e.g., Press Release, Amnesty Int'l, United Kingdom: "Bolton 7"-Prisoners of Conscience if Imprisoned, Index: EUR 45/02/98 (18 Feb. 1998); Amnesty Int'l, United 
fear that adolescents might give in to curiosity and experiment with sexual acts with individuals of the same sex and must, therefore, be protected by prejudicially higher ages of consent neglects the barriers that they must overcome to accept their sexual orientation or gender identity.

The UN Committee on the Rights of the Child (CRC) has recognized that one of the challenges adolescents face is "developing an individual identity and dealing with one's sexuality."114 The CRC also expressed concern that in the United Kingdom "homosexual and transsexual young people do not have access to the appropriate information, support and necessary protection to enable them to live their sexual orientation." 115 Given that LGBT adolescents have to live in environments so often full of discrimination, harassment, and even violence on the basis of their sexuality, their decision to accept themselves in spite of that opposition suggests that they may know themselves and be making more informed choices than their heterosexual counterparts who are not questioned over their heterosexuality. ${ }^{116}$ Any lack of knowledge merely argues for adequate, balanced sex education that includes information on various sexualities and gender identities. ${ }^{117}$ This explains why elimination of homophobia within the educational system is key to ending discrimination on the grounds of sexuality.

\section{Pro-Procreation Concerns}

The prohibitions on same-sex marriage have also been defended by state authorities as necessary to ensure the sanctity of marriage as a bond to foster procreation for the perpetuation of the human race. ${ }^{118}$ Invested in maintaining a culture of heterosexuality, the state gives primacy to procreative sex and the "conjugal bed" by criminalizing same-sex intercourse. In doing so, the state rejects claims of the human rights of LGBT individuals and erodes efforts of women's human rights defenders to challenge stereotypes of the

Kingdom: Time to Repeal Anti-Gay Criminal Laws, Index: EUR 45/011/1998 (1 May 1998).

114. Comm. on the Rts. of the Child, General Comment No. 4, Adolescent Health and Development in the Context of the Convention on the Rights of the Child, U.N. GAOR, 33d Sess., ๆ 2, U.N. Doc. CRC/GC/2003/4, (1 July 2003).

115. Comm. on the Rts. of the Child, Concluding Observations: United Kingdom of Great Britain and Northern Ireland, I 43, U.N. Doc. CRC/C/15/Add.188, (2 Oct. 2002).

116. Phil C.W. Chan, No, It Is Not Just a Phase: An Adolescent's Right to Sexual Minority Identity Under the United Nations Convention on the Rights of the Child, 10 INT'L J. Hum. RTs. 161, 166 (2006) available at http://ipac.kacst.edu.sa/eDoc/2006/159315_1. $p d f$.

117. Id.

118. See, e.g., Kerrigan v. Commissioner of Public Health, 957 A.2d 407, 515-16 (Conn. 2008) (Zarella, J., dissenting); Conway v. Deane, 932 A.2d 571, 619-21 (Md. Ct. App. 2007); Fellmeth, supra note 18, at 886. 
"feminine ideal" and retain the archaic tradition of seeing women as wives and mothers. ${ }^{119}$ Granted, marriage is "an underlying biological complementarity which, for many, includes the possibility of procreation."120 However, Judge Walker in Perry v. Schwarzenegger challenged such a worldview, holding that:

Never has the state inquired into procreative capacity or intent before issuing a marriage license; indeed, a marriage license is more than a license to have procreative sexual intercourse. "[I]t would demean a married couple were it to be said marriage is simply about the right to have sexual intercourse." The Supreme Court recognizes that, wholly apart from procreation, choice and privacy play a pivotal role in the marital relationship. ${ }^{121}$

It is true that heterosexual marriages are considered primary for fostering procreation. Generally, however, states do not require marriage as a precondition to procreation nor do they require procreation as a condition of marriage. In fact, some heterosexual couples marry with no intent to procreate. ${ }^{122}$ Moreover, reproduction occurs outside of marriage and is not a criminal act in modern state practice. Further, the impossibility of procreation due to impotence or sterility can vehemently be challenged as a valid ground for divorce in modern family law. Again, Judge Walker held that:

Whether same-sex marriages are allowed or prohibited can have at most a tenuous relation to procreation rates in different sex marriage. Laws disadvantaging unconventional sexuality and lifestyles may offer a kind of indirect public approval of the procreative possibility, but the incentive is neither clear nor direct. It would be absurd to argue that a homosexual who is denied the right to marry another person of his or her own sex will switch sexual orientations and marry someone of a different sex. ${ }^{123}$

Criminalizing unconventional sexual intercourse or same-sex marriages merely stigmatizes sexual minorities and forces them underground; "it cannot turn them into heterosexual baby factories by legislative fiat." ${ }^{\prime 24}$ The notion of marriage has evolved in recent times such that procreation can no longer be said to form an integral part of marriage. If procreation is considered beneficial to the state, then a direct way of encouraging it is not to criminalize same sex-relationships, but to reward procreation with subsidies or benefits for those able and inclined to procreate. ${ }^{125}$ Further, the very premise of the

119. Alexander, supra note 103 , at 147-48.

120. See, e.g., Church of England Warning on Gay Marriage, supra note 91.

121. Perry v. Schwarzenegger, 704 F. Supp. 2d 921, 992 (N.D. Cal. 2010); Lawrence, supra note 41 at 567; Griswold v. Connecticut, 381 U.S. 479, 485-86 (1965).

122. Fellmeth, supra note 18 , at 887.

123. Id. at 888 .

124. Id.

125. Id. 
argument that the state has a legitimate interest in fostering procreation is less persuasive in a badly overpopulated world. ${ }^{126}$ Furthermore, while same-sex couples may legally adopt children, queer sexual activities do not necessarily preclude procreation, as those who wish to procreate may do so following technological advances such as artificial insemination.

\section{TO CRIMINALIZE HOMOSEXUALITY OR TO DE-CRIMINALIZE HOMOPHOBIA?}

In addition to the discrimination against people practicing queer sexuality, the other problem concerns the criminalization of queer sexual activities. A distinction should be made between homosexual offences and homosexuality in that: "Homosexuality is a sexual propensity for persons of one's own sex." Homosexuality, then, is a "state or condition which 'as such does not, and cannot, come within the purview of the criminal law.'"127

The so-called sodomy offences are punished regardless of where the proscribed conduct took place; whether it is made in public or in private. A sodomy law is a law that defines certain sexual acts as crimes. The precise sexual acts meant by the term sodomy are rarely spelled out in the law, but are typically understood by courts to include any sexual act deemed "unnatural. ${ }^{128}$ These acts typically include oral sex, anal sex, and bestiality; in practice such laws have rarely been enforced against heterosexual couples. ${ }^{129}$ In short, such laws are homophobic. According to Alexy: "The words 'discrimination' and 'equality' are ambiguous, referring both to the mere fact of difference (or justified similarity) of treatment and also to unjustified difference (or justified similarity, or indeed justified difference) of treatment."130

There is discrimination when states without an objective and reasonable justification fail to treat differently persons whose situations are significantly different. ${ }^{131}$ For example, the apparent bases for enactment of the US Defense of Marriage Act (DOMA) included "(1) defending and nurturing the institution of traditional, heterosexual marriage; (2) defending traditional notions of morality; (3) protecting state sovereignty and democratic self-governance; and (4) preserving scarce government resources."132

\section{Id.}

127. Sir J. Wolfenden, Report of the Departmental Committee on Homosexual Offences and Prostitution, International Congress on Clincial Chemistry 639 (1957).

128. Jeffrey Weeks, Sex, Politics and Society: The Regulation of Sexuality Since 1800, at 99 (2d. ed. 1989).

129. Andrew Sullivan, Unnatural Law, New Repubuc, 27 Mar. 2003, available at http://www. tnr.com/article/unnatural-law.

130. Robert Alexy, A Theory of Constitutional Rights, at xix, xlv-vi (2004).

131. Thlimmenos v. Greece, App. No. 34369/97, 31 Eur. H.R. Rep. 15, ฯ 44 (2000).

132. Commonwealth of Massachusetts v. US Dept. of Health \& Human Services, 698 F. Supp.2d 234 (Mass. D. Ct. 2010) [hereinafter C'wealth of Mass.] (see Petition for Writ 
In many cases, however, governments do not give compelling arguments, if at all, as to why it would treat people differently on the grounds of their sexuality. Some states have extended "anti-sodomy" laws to lesbians and heterosexual activity ostensibly to avoid the claims of discrimination. ${ }^{133}$ As such, criminalization leaves open to debate "critical and relatively subjective decisions about what kind of regulation is necessary, what social needs are pressing, and what kind of regulation is proportionate to the aim pursued." ${ }^{\prime 34}$ Several human rights monitoring bodies have repeatedly and consistently called for the repeal of laws criminalizing queer sexuality across the globe. ${ }^{135}$ Further, various treaty bodies have also considered the principle of non-discrimination on grounds of sexual orientation as one that is firmly grounded in international standards, requiring not only the repeal of discriminatory criminal laws but also the adoption of proactive anti-discrimination measures." 136

\section{A. Sexuality and Sexual Relationships}

Amnesty International has observed that individuals may engage in same sex practices without regarding their behavior or claiming an identity based on that behavior. It is not one's sexual orientation that counts but one's practice. Thus, "individuals are discriminated against on the basis of what they do, or are presumed to be doing." ${ }^{137}$ It has been noted that: "The notion that there are two and only two genders is one of the most basic ideas in our binary Western way of thinking. Transgender people challenge our very understanding of the world. And we make them pay the cost of our confusion by their suffering." 138

In many countries, sex between individuals of the same sex is criminalized in vague terms. ${ }^{139}$ Such offences are couched, for example, as "carnal

of Certiorari, available at: http://www.justice.gov/osg/briefs/2012/2pet/7pet/2012-0015. pet.aa.pdf); Gill v. Office of Personnel Management, 682 F.3d 1, 14 (1st Cir. 2012).

133. Hum. Rts. Comm., Consideration of Reports Submitted by States Parties Under Article 40 of the Covenant: Malawi, U.N. Doc. CCPR/C/MWI/1 (13 July 2012), available at http://www.bayefsky.com/reports/malawi_ccpr_c_mwi_1_2012.pdf [hereinafter Malawi Report]; see Malawi Government, Penal Code (Amendment) Act of 2011 of the Laws of Malawi, § 137A [hereinafter Malawi Penal Code].

134. Fellmeth, supra note 18, at 808.

135. Saiz, supra note 3 , at 6 .

136. Id. at 8, n.31.

137. Amnesty Int'L, Love, Hate and the Law, supra note 14 , at 6.

138. O'Flaherty \& Fisher, supra note 35, at 207, 209 n.9, quoting a Canadian Report.

139. See Republic v. Soko \& Kachepa [Chief Resident Magistrate's Court] 20 May 2010 [2010] MWHC 2 (Malawi) (In a case of same sex relationship, the court found that the mere fact that the defendants held a public engagement ceremony and that they lived as "husband" and "wife"' was conclusive evidence that the section 156-offence had been proven. With flawed logic, the court made a connection between one's sexuality and intercourse.). 
knowledge against the order of nature," "gross indecency," or "unnatural offences." Such offences are collectively called anti-sodomy laws or wrongly dubbed as anti-homosexuality laws. ${ }^{140}$ Human sexuality is a nuanced conception and is premised upon emotional and physical attraction of the various sexes; not coitus, i.e., sexual intercourse. ${ }^{141}$ The proscriptions envisaged under these provisions do not address sexuality, but rather coitus. ${ }^{142} \mathrm{As}$ argued earlier, these so-called anti-sodomy laws are, in actual sense, homophobic laws.

A notable provision of such unnatural offences is Section 153 of the Penal Code of the Laws of Malawi, which provides that "any person who, (a) has carnal knowledge of any person against the order of nature; or (b) has carnal knowledge of an animal; or (c) permits a male person to have carnal knowledge of him or her against the order of nature, shall be guilty of a felony and shall be liable to imprisonment for fourteen years." ${ }^{143}$ The Malawian Penal Code also recently broadened its anti-sodomy laws to include "indecent practices between females" in Section 137A, which reads:

Any female person who, whether in public or private, commits any act of gross indecency with another female person, or procures another female person to any act of gross indecency with her, or attempts to procure the commission of any such act by any female person with herself or with another female person, whether in public or private, shall be guilty of an offence and shall be liable to imprisonment for five years. ${ }^{144}$

Section 137A seeks to punish acts of gross indecency among female persons, in public or in private, similar to the offence of gross indecency among male persons under Section 156, which proscribes indecent practices between males. ${ }^{145}$ The offence is committed regardless of where the proscribed conduct took place; whether it is made in public or in private. What amounts to an act of gross indecency is not stipulated in the Act. ${ }^{146}$ In fact, Section 137A seeks to "prohibit any type of sexual relations between females; does it then constitute a blanket prohibition of all forms of human female sexuality whether as it may be depicted by a lesbian or a bisexual?"147

140. See id. at 13. (In its analysis of the anti-sodomy laws in Malawi, the Malawi Law Commission has aptly noted that the anti-sodomy provisions are wrongly called "antihomosexuality laws" based on a moral indictment rather than a legal one.)

141. Id

142. The language of such provisions does not proscribe homosexuality as such. An act of "'gross indecency,' 'carnal knowledge against the order of nature,' 'buggery,' 'sodomy,' etc, does not immediately follow that it proscribes a person's sexuality." Id. at 15.

143. R v. Jacobs, 168 E.R. 830 (1817) (the High Court of Malawi, confirmed that Section 153 of the Penal Code is a strictly an anti-sodomy law and does not cover oral sexual penetration).

144. Malawi Penal Code, supra note 133, § 137A.

145. Malawi Law Comm'n, supra note 139.

146. Id. at 13-14; see also Morris B. Kaplan, Sodom on the Thames: Sex, Love and Scandal in Wilde Times (2005).

147. Malawi Law Commission, supra note 139 , at 13. 
Although the "unnatural" acts may include oral sex between a married heterosexual couple, it is only consensual same-sex sexual activity that is prosecuted. ${ }^{148}$ The commonly held view is that "only penile-vaginal penetration (that bears the potential of procreation) conforms to the stated order of nature."149 The language of unnatural offences demonstrates an underlying medical view of homosexuality as a form of mental illness or psychopa-thology that psychiatric treatment can resolve. ${ }^{150}$ This is in contradiction to evidence to the contrary from psychiatry experts and the World Health Organization (WHO). ${ }^{151}$

\section{B. Non-Discrimination of Sex(uality)}

By institutionalizing discrimination, laws criminalizing queer sexuality reinforce systemic prejudice against LGBT persons, "who may be heterosexual, and act as an official incitement to or justification for violence against them, whether in custody, in public or private." ${ }^{\prime 152}$ Any law that discriminates against a person on the basis of their sexuality is discriminatory on the basis of sex. Conversely, it can be argued that anti-sodomy laws discriminate on the basis of sex alone because, practically, the criminality of a sexual act committed by a man turns on the gender of his sexual partner. In other words, if a sexual act committed by a man is legal when committed with a woman, but illegal when committed with a man, the law itself is discriminatory on the basis of the gender of the sexual partner. ${ }^{153}$

The "call for decriminalization of consensual sexual behavior (between the same or different sexes) begs the question of which conditions justify limits or restrictions on sexual behavior, especially through criminal law." 154 The flexibility inherent in the ordre public and morality exceptions has long been used by states to justify the systemic oppression of and discrimination against classes of persons defined as sexual deviants and other sexual practices. ${ }^{155}$ Amnesty International counsels that:

148. Voices Against 377, Rights for All: Ending Discrimination against Queer Desire under Section 377 (2005).

149. Baudh, supra note 86 , at 5 .

150. Deborah Cameron \& Don Kulick, Language and Sexuality (2003).

151. For example, the American Psychiatric Association had removed homosexuality as a disorder from the "Sexual Deviancy" section of the Diagnostic and Statistical Manual of Mental Disorders (2d ed. 1973). In 1992, the WHO replaced its categorization of homosexuality as a mental illness. Several states then followed suit. Jack Drescher, Queer Diagnoses: Parallels and Contrasts in the History of Homosexuality, Gender Variance, and the Diagnostic and Statistical Manual, 39 ArCh. Sex. Benav. 427, 435 (2010).

152. AmNesty INT'L, Love, Hate AND the LaW, supra note 14 , at 5.

153. Id. at 5 .

154. Sexuality and Human Rights, supra note 4, at 15.

155. Fellmeth, supra note 18 , at 808. 
Such laws, even when not implemented, construct societal attitudes, sending a clear message of, at best, second-class citizenship to people who identify as lesbian, gay, bisexual or transgender, or anyone who engages in any form of consensual same-sex sexual conduct, or those whose self-defined gender identity or gender expression differs from acceptable "norms" of gender and sexuality. It is not just the conduct that is denounced by law but the individual who performs it. Such laws encourage private and state acts of violence and fuel impunity for those acts. Instead, states should provide a series of rights protections and take actions to promote human rights to create the necessary enabling conditions to ensure that people are able to enjoy sexual rights and find love. ${ }^{156}$

Some have argued that the "principle of nondiscrimination on grounds of sexual orientation cannot be considered as universally recognized as it does not appear in any UN treaty." ${ }^{157}$ However, in Toonen v. Australia, the Human Rights Council (HRC) found that the Tasmanian laws criminalizing all sexual relations between men were in breach of the International Covenant on Civil and Political Rights (ICCPR). ${ }^{158}$ The HRC opined that discrimination based on sexual orientation was forbidden by Articles 26 (equality before the law) and 2(1) (non-discrimination) under the rubric of discrimination based on sex. ${ }^{159}$

Further, in Joslin v. New Zealand, it was categorically stated that, the prohibition against discrimination on grounds of sex in Article 26 comprises also discrimination based on sexual orientation. ${ }^{160}$ The HRC held that the term sex refers to both gender as well as sexual orientation, implying that that the principle of non-discrimination on the grounds of sex includes sexual orientation. ${ }^{161}$ The CRC has also found that the laws prohibiting the "promotion of sexuality" or the setting of a higher age of sexual consent for the same-sex relations are in breach of the non-discrimination provisions of the Convention on the Rights of the Child. ${ }^{162}$

It is trite law in human rights instruments that each fundamental rightincluding the right to marry - should be ensured to all individuals without distinction of any kind, such as sex or other status. ${ }^{163}$ Article 21(1) of the

156. Amnesty Int'L, Love, Hate And the LaW, supra note 14 , at 7.

157. See, e.g., Saiz, supra note 3, at 12 .

158. It should be noted the Federal Government of the Commonwealth of Australia was opposed to the Tasmanian law in question. Toonen v. Australia, HRC, Commc'n No. 488/1992, ฯ 8(7), U.N. Doc. CCPR/C/50/D/488/1992 (31 Mar. 1994).

159. Id.

160. Joslin v. New Zealand, HRC, Commc'n No. 902/1999, U.N. Doc. CCPR/C/75/D/902/1999 (2003) (An individual concurring opinion of two HRC members).

161. Toonen, supra note 158, I 8(7); see also Waaldijk, supra note 12, ๆ 4.

162. Comm. on the Rts. of the Child, Concluding Observations of the Committee on the Rights of the Child: United Kingdom, I 44, U.N. Doc. CRC/C/15/Add.188, (2 Oct. 2002); Comm. on the Rts. of the Child, Concluding Observations of the Committee on the Rights of the Child: United Kingdom, I 22-23, U.N. Doc. CRC/C/15/Add.134 (16 Oct. 2000).

163. See International Covenant on Civil and Political Rights, adopted 16 Dec. 1966, G.A. Res. 2200 (XXI), UN GAOR, 21st Sess., arts. 2(1), 26, U.N. Doc. A/6316 (1966), 999 U.N.T.S. 171 (entered into force 23 Mar. 1976) [hereinafter ICCPR]. 
Charter of Fundamental Rights of the European Union explicitly states that "[a]ny discrimination based on any ground such as sex, race, color, ethnic or social origin, genetic features, language, religion or belief, political or other opinion, membership of a national minority, property, birth, disability, age or sexual orientation shall be prohibited." African states need to follow the example of South Africa, which is the only African country where samesex marriages are legal and discrimination based on sexual orientation is explicitly proscribed in the Constitution. Criminalization of homosexuality does not prevent the proscribed consensual sexual acts, nor is it the only barrier to full equality. Decriminalization is not the panacea, but it is "a key step towards respecting, protecting and fulfilling the human rights of LGBT people." 164 It is also incumbent upon governments to ensure that that sexuality rights are respected both in policy and practice.

\section{Equality of Sexuality: Recognition of Same-Sex Relationships}

Equality is not simply a matter of likeness. It is equally a matter of difference. That those who are different should be treated differently is as vital to equality as is the requirement that those who are alike be treated alike. In certain cases, it is the very essence of equality to make distinctions between groups and individuals in order to accommodate their different needs and interests. ${ }^{165}$ These were exactly the bases of present constitutional challenges to Section 3 of DOMA, which denies federal economic and other benefits to same-sex couples lawfully married in Massachusetts and to surviving spouses from couples thus married. ${ }^{166}$ The plaintiffs contended that DOMA should be condemned "because its unacknowledged but alleged central motive was hostility to homosexuality."167 Although legislators who supported DOMA acted from a variety of motives, "one central and expressed aim being to preserve the heritage of marriage as traditionally defined over centuries of Western civilization." ${ }^{168}$ The court held that "Congress' denial of federal benefits to same-sex couples lawfully married in Massachusetts has not been adequately supported by any permissible federal interest."169

DOMA does not invalidate same-sex marriages in states that permit them per se, but its adverse consequences for such a choice are considerable. For example, it prevents same-sex married couples from filing joint federal tax

164. Amnesty Int'L, Love, Hate and the Law, supra note 14 , at 5.

165. ALEXY, supra note 130, at xlvi-xlvii.

166. Defense of Marriage Act (DOMA), 1 U.S.C. $\$ 7$ (1996), available at http://www.gpo. gov/fdsys/pkg/BILLS-104hr3396enr/pdf/BILLS-104hr3396enr.pdf.

167. C'wealth of Mass., supra note 132, at 19a.

168. Id. at 23a.

169. Id. at 24a. 
returns, which can lessen tax burdens, and prevents the surviving spouse of a same-sex marriage from collecting Social Security survivor benefits. "[T] he combined effect of DOMA's restrictions on federal benefits [does] not prevent same-sex marriage where permitted under state law; but it [does] penalize those couples by limiting tax and social security benefits to opposite-sex couples in their own and all other states." ${ }^{\prime 170}$ Differential treatment of different cases is at the core of the right to equality. In National Coalition for Gay and Lesbian Equality v. Minister of Justice, Justice Sachs opined that:

[E]quality should not be confused with uniformity; in fact uniformity can be the enemy of equality. Equality means equal concern and respect across difference. It does not presuppose the elimination or suppression of difference. Respect for human rights requires the affirmation of self, not the denial of self. Equality therefore does not imply a leveling or homogenisation of behaviour but an acknowledgement and acceptance of difference. At the very least, it affirms that difference should not be the basis for exclusion, marginalisation, stigma and punishment. At best, it celebrates the vitality that difference brings to any society. ${ }^{171}$

Differential treatment amounts to discrimination if: the inferior treatment places the person at a disadvantage or deprives him of his access to benefits, privileges, or rights; the differentiation is based on the prohibited or analogous ground; and the differentiation is unreasonable or unjustifiable. ${ }^{172}$ Gross indecency laws or anti-sodomy laws make a clear distinction in their application between heterosexuals and homosexuals. While the letter of the law proscribes both homosexual and heterosexual sodomy, in reality only homosexuals are harassed because only homosexuals, and specifically homosexual men, are presumed to commit sodomy during the course of a sexual relationship.

Therefore . . practically speaking, sodomy is only criminalized when it occurs between homosexuals; but it is permissible when it occurs between heterosexuals. . . . Such laws are clearly in violation of [equality and nondiscrimination provisions under a] constitution because it does not apply equally to hetero-sexuals and homosexuals. ${ }^{173}$

170. Id. at $13 \mathrm{a}$.

171. National Coalition for Gay and Lesbian Equality v. Minister of Justice, (CCT11/98) [1998] ZACC 15; 1999 (1) SA 6; 1998 (12) BCLR 1517 (S. Afr.) [hereinafter NCGLE v. Minister of Justice]; see also ICCPR, supra note 163, arts. 2, 3, 26; Banjul Charter, supra note 5, art. 2.

172. Anne Sakala v. Registered Trustees of the Designated Schools Board, Civil Cause No. 2652 of 1999 (Unreported).

173. Michael Hollander, Gay Rights in Uganda: Seeking to Overturn Uganda's Anti Sodomy Laws, 50 VA. J. INT'L L. 219, 259 (2009). 
Addressing the issue of excluding same-sex couples from the benefits and responsibilities of marriage, Justice Sachs in Fourie and Another v. Minister of Home Affairs and Another opined that the case:

represents a harsh if oblique statement by the law that same-sex couples are outsiders, and that their need for affirmation and protection of their intimate relations as human beings is somehow less than that of heterosexual couples. It reinforces the wounding notion that they are to be treated as biological oddities, as failed or lapsed human beings who do not fit into normal society, and, as such, do not qualify for the full moral concern and respect that our Constitution seeks to secure for everyone. It signifies that their capacity for love, commitment and accepting responsibility is by definition less worthy of regard than that of heterosexual couples. ${ }^{174}$

Civil unions should not be created as a means to deny equal rights to samesex couples or heterosexual couples who for whatever reason do not want to be married. Human Rights Watch observed that:

while civil unions have represented progress, states still have an obligation to equality. Civil unions do not carry the same promises of recognition across international borders that marriage ordinarily implies. The burden is on governments to justify refusing recognition to foreign marriages, but the burden usually —and unfairly - rests on partners in civil unions to justify their recognition abroad. ${ }^{175}$

The very creation of a separate system of family rights for homosexuals may be taken as a denial of the equal dignity and value of homosexual relationships to heterosexual ones. ${ }^{176}$ Human Rights Watch has also noted that:

the segregation of same-sex unions into a special legal status is a form of "separate but equal" acknowledgement. Separate is never equal: the experience of racial segregation in the United States testifies eloquently to how preserving discreteness only perpetuates discrimination. Even if the rights promised by civil unions on paper correspond exactly to those entailed in civil marriage, the insistence on a distinct nomenclature means that the stigma of second-class status will still cling to those relationships. ${ }^{177}$

To be clear, what same-sex couples demand is marriage equality with different sex couples in all aspects of their lives, including family life. This

174. Per Justice Albie Sachs in Fourie and Another v. Minister of Home Affairs and Another, [2004] ZASCA 132, SCA 971 (S. Afr.).

175. Human Rights Watch (HRW), Non-Discrimination in Civil Marriage: Perspectives from International Human Rights Law and Practice, A Human Rights Watch Briefing Paper (2003), available at http://www.hrw.org/legacy/backgrounder/lgbt/civil-marriage.htm; HRW, U.S.: Same-Sex Marriage Ruling Upholds Equality Under Law (2003), available at http://www.hrw.org/news/2003/02/06/us-same-sex-marriage-ruling-upholds-equalityunder-law.

176. Fellmeth, supra note 18 , at 859.

177. HRW Briefing Paper, supra note 175. 
means that same-sex marriages should be recognized on the same basis as married heterosexual couples. Recognition of same-sex marriages and non-discriminatory respect for family life not only demands that same-sex partners shall be awarded (all or certain) spousal benefits, but also requires that the law provides procedures and a status to ensure the legal certainty of all persons concerned. ${ }^{178}$

The current state of international law seems to be quite clear on two points: discrimination between unmarried different-sex cohabitants and unmarried same sex cohabitants is prohibited, and exclusion of same-sex couples from marriage is still permissible. In between those two points the field is less clear. There is growing support for the proposition that a registered partnership or same sex marriage validly contracted in one country should be recognized by international organizations and — for certain purposes_-also by other countries. There are reasons to expect that international bodies will apply the prohibition of indirect discrimination to situations where same-sex partners are being excluded from certain legal benefits because they are only available to married partners. This indirect discrimination argument, which focuses on the provision of specific benefits, rather than on the granting of status, has been accepted already in several domestic courts. ${ }^{179}$ According to Mutua:

Formal equality seeks to guarantee a simple notion-that every individual is endowed with inherent and intrinsic worth as a human being and that no one human being is more important than another in terms of their inherent worth. This notion categorically captured in the Universal Declaration of Human Rights, which provides [. . .] that "All human beings are born free and equal in dignity and rights." That statement is unequivocal and does not condition equality on identity such as sexual orientation. ${ }^{180}$

Equal protection and non-discrimination are the two basic principles that arise for the notion of formal equality, embodying human freedom and liberty. ${ }^{181}$ "Equal protection guarantees against discrimination and vice versa. Discrimination is prohibited because equal protection is required."182 Equality entails embracing those with queer sexuality rather than stigmatizing or ostracizing them. Tolerance is the key. To tolerate means not only to refrain from exercising political sanctions to make a people change its ways, but also "to recognize these non-liberal societies as equal participating members in good standing of the Society of Peoples."183

178. Waaldijk, supra note 12 , ๑ 7 .

179. Id.

180. Mutua, supra note 2, at 455 .

181. Id. at 455 .

182. Id.

183. John Rawls, The Law of Peoples 59 (1999). 
There is also a non-instrumental reason to grant them respect: it is their due. In the absence of a clear guarantee on sexuality rights, claims of nondiscrimination are the most effective way of increasing the international protection of same-sex partnership. ${ }^{184}$ The idea of "sexual citizenship" serves to capture the ways in which sexual difference or conformity influences the ability of individuals to participate in political society, or excludes them. It is meant also to suggest that multiple rights need to be fulfilled in order for a person to participate as a full member of his or her local or national polity. ${ }^{185}$ According to present day perceptions, marriage concerns a permanent union of two individuals encompassing all aspects of life.

\section{D. "Sex on the Beach?": Protecting Privacy Rights}

Anti-sodomy "laws allow law enforcement officials to invade the private residences of individuals alleged to be engaging in consensual same-sex sexual relations." ${ }^{186}$ "The central question is what is the rationale and scope of the state's role in regulating sexuality in public and private life?"187 "Proponents for decriminalization of same-sex sexual activity argue that such laws violate the rights to privacy, that they are examples of 'victimless crimes' that should not be criminalized, and that even when not enforced, such laws harm sexual minorities in unjustifiable ways." 188 "The boundaries of the right to privacy have proven highly mutable, and respect for privacy can co-exist with moral disapproval or mere tolerance of homosexuality, as long as it is confined to the private sphere of the closet."189 Fellmeth views the right to privacy "not merely as the freedom to maintain secrecy, but as freedom of intimate conduct, association, and expression without fear of arbitrary state interference." ${ }^{\prime 190}$

The elasticity of the principles of privacy has been used to address both over-invasive and neglectful behavior by governments. "However, if values that support privacy claims are not made explicit, sexuality can be divorced from social context and its application can be confined narrowly to individuals' physically intimate behaviour." 191 The question remains that if

184. Waaldijk, supra note 12 , 6 .

185. Mathew Waites, The Age of Consent and Sexual Citizenship in the United Kingdom: A History, in Relating Intimacies: Power and Resistance (Julie Seymour \& Paul Bagguley eds., 1999).

186. Amnesty INT'L, Love, Hate And the LaW, supra note 14 , at 5.

187. Rubin, supra note 39, 267.

188. Edward Stein, Evaluating the Sex Discrimination Argument for Lesbian and Gay Rights, 49 UCLA L. Rev. 471, 475 (2001) 475.

189. Saiz, supra note 3 , at 17 .

190. Fellmeth, supra note 18 , at 802.

191. Sexuality and Human Rights, supra note 4, at 37 (internal footnotes removed). 
the objective of the law is to protect the society, what harm does an act that happens behind lock and key by two consenting adults do to the society?

In Dudgeon v. United Kingdom, in considering whether this invasion of the private life of the applicant on allegations of "buggery" and "gross indecency" could be justified for the protection of morality, the ECtHR found that none of the various social and political factors it considered could qualify the legislation as "necessary or appropriate" in a democratic society. The reasoning of the court was that even though those who find homosexuality immoral may be shocked, offended, or disturbed by the commission of private homosexual acts, that on its own cannot warrant intrusion of their privacy when only consenting adults are involved. ${ }^{192}$

Similarly, in Lawrence v. Texas, the US Supreme Court found state statutes criminalizing homosexual conduct to be an unconstitutional intrusion on freedom and privacy. ${ }^{193}$ In these decisions, the courts emphasized the intimacy of sexual behavior and the centrality of sexual conduct to one's identity and personality as a reason for treating the matter as falling within a right to privacy. ${ }^{194}$ Likewise in Norris $v$. Ireland, the criminalization of such practices was deemed a violation of the privacy protection in Article 8 of the ECHR. ${ }^{195}$ In Modinos v. Cyprus, the ECtHR again held that such a law violated the right to privacy, and maintained that even a consistent policy of not bringing prosecutions under the law was no substitute for full repeal. ${ }^{196}$ More importantly, in $R$ v. British Broadcasting Standards ex parte BBC, Lord Mustill articulated that:

[T] he privacy of a human being denotes at the same time the personal "space" in which the individual is free to be itself, and also the carapace, or shell, or umbrella, or whatever other metaphor is preferred, which protects that space from intrusion. An infringement of privacy is an affront to the personality, which is damaged both by the violation and by the demonstration that the personal space is not inviolate. ${ }^{197}$

In short, discrimination in the criminal law regarding consenting relations between adults in private is contrary to the right to respect for private life. ${ }^{198}$ According to Judge Walker:

The Due Process Clause provides that no "State [shall] deprive any person of life, liberty, or property, without due process of law." . . . Due process protects

192. Dudgeon v. United Kingdom, App. No. 7525/76, 4 Eur. H.R. Rep. 149, ฯ 60 (1982).

193 Lawrence, supra note 41.

194. See, e.g., NCGLE v. Minister of Justice, supra note 171.

195. Norris v. Ireland, App. No. 10581/83, 13 Eur. H.R. Rep. 186 (1988).

196. Modinos v. Cyprus, App. No. 15070/89, 16 Eur. H.R. Rep. 485 (1993).

197. R v. British Broadcasting Standards ex parte BBC, [2001] QB 885, I 45.

198. See European Convention on Human Rights, opened for signature 4 Nov. 1950, art. 8, 213 U.N.T.S. 221, Europ. T.S. No. 5 (entered into force 3 Sept. 1953); see also Dudgeon, supra note 192 . 
individuals against arbitrary governmental intrusion into life, liberty or property [. . .] When legislation burdens the exercise of a right deemed to be fundamental, the government must show that the intrusion withstands strict scrutiny. . . . The freedom to marry is recognized as a fundamental right protected by the Due Process Clause. ${ }^{199}$

In National Coalition for Gay and Lesbian Equality v. Minister of Justice, the South African Constitutional Court held that punishing the offense of sodomy is unconstitutional because it breaches the right to equality, dignity, and privacy. "[T] he constitutional protection of dignity requires us to acknowledge the value and worth of all individuals as members of our society." 200 The reasoning of the Court was that:

The common law prohibition on sodomy criminalises all sexual intercourse per anum between men: regardless of the relationship of the couple who engage therein, of the age of such couple, of the place where it occurs, or indeed of any other circumstance whatsoever. In so doing, it punishes a form of sexual conduct which is identified by our broader society with homosexuals. Its symbolic effect is to state that in the eyes of our legal system all gay men are criminals. ... There can be no doubt that the existence of a law which punishes a form of sexual expression for gay men degrades and devalues gay men in our broader society. As such it is a palpable invasion of their dignity and a breach of section 10 of the Constitution. ${ }^{201}$

In concurring, Justice Sachs noted that privacy must be regarded as "suggesting at least some responsibility on the state to promote conditions in which personal self-realisation can take place." 202 "That is not to say that people should be allowed to do anything they like in private; states are obliged to act to prevent harm." ${ }^{203}$ Criminalization of certain consensual sexual acts on the basis of sexual orientation is a violation of equality: "The expression of sexuality requires a partner, real or imagined. It is not for the state to choose or to arrange the choice of partner, but for the partners to choose themselves." 204 In sum, the right to privacy as the right to private space, private side of life, and the liberty to be left alone is an established norm under international human rights law. The state's interference with the privacy of consenting adults engaging in queer sexual acts is a violation of

199. Perry, supra note 121, at 991.

200. NCGLE v. Minister of Justice, supra note 161.

201. Id.

202. Id. I 116; see also Timothy Otty, et al, The Commonwealth and the Criminalisation of Homosexuality: An Overview, Paper prepared for Meeting of Senior Officials of Commonwealth Law Ministries Marlborough House, London, 18-20 Oct. 2010, available at http://www.humanrightsinitiative.org/london/lgbt_rights/SOLM_Paper_on_Criminalisation_of_Homosexuality(1).pdf.

203. Amnesty INT'L, Love, Hate and the Law, supra note 14, at 34.

204. NCGLE v. Minister of Justice, supra note 171, ๆ 117. 
the "most private human conduct, sexual behavior, and in the most private of places." 205

\section{E. One Wo(man) and One Wo(man): The Right to Marry}

The concept of marriage has been, and still is, often interpreted in the traditional heterosexual sense. At common law, a marriage between persons of the same sex was void ab initio. In the 1866 case of Hyde v. Hyde, Lord Penzance defined marriage "as understood in Christendom is the voluntary union for life of one man and one woman, to the exclusion of all others. ${ }^{206}$ In the 1967 case of Talbot (otherwise Poyntz) v. Talbot, the prohibition was held to extend where one spouse was a post-operative transsexual, and that marriage "is a relationship which depends on sex, not on gender." ${ }^{207}$ In 1971 the Nullity of Marriage Act was passed, explicitly banning marriages between same-sex couples in England and Wales. Likewise in the United States, DOMA was enacted with Section 3 stating "the word 'marriage' means only a legal union between one man and one woman as husband and wife, and the word 'spouse' refers only to a person of the opposite sex who is a husband or a wife." 208

Unsurprisingly, DOMA was challenged on the basis, among others, that the US Congress undercut the choices made by same-sex couples and by individual states in deciding who can be married to whom. ${ }^{209} \mathrm{~A}$ few jurisdictions have introduced some form of registered partnership-also called civil partnership, civil union, civil pact, etc. The structure, procedure, status, and legal consequences attached to these new legal forms tend to be similar to those of marriage, although in some jurisdictions there is still a significant difference between the legal content of marriage and the legal content of registered partnership. ${ }^{210}$ In the United Kingdom, civil partnerships have been introduced as kneejerk reaction to give same-sex couples the same legal rights as married couples, but the law does not allow such unions to be referred to as marriages. ${ }^{211}$ Although this may not be seen as a problem, the fact that there are distinctions on marital relationships manifests discrimination.

205. Lawrence, supra note 41.

206. Hyde v. Hyde and Woodmansee [L.R.] 1 P. \& D. 130 (1866).

207. House of Commons, Ground on Which Marriage is Void (12 Apr. 1971), available at: http://hansard.millbanksystems.com/commons/1971/apr/02/grounds-on-which-amarriage-is-void\#column_1829.

208. DOMA, supra note $166, \S 7$.

209. U.S. v. Windsor, 133 S.Ct. 2675 (2013).

210. HRW Briefing Paper, supra note 175.

211. House of Commons Standing Committee D (Pt. 4), Civil Partnership Bill [Lords], available at http://www.publications.parliament.uk/pa/cm200304/cmstand/d/st041021/am/41021s04. htm. 
For example, in Wilkinson v. Kitzinger, the parties were legally married in Canada, but when they moved to the United Kingdom their marriage was not recognized under British law. The couple sued for recognition of their marriage contending that it was recognized by the lex loci celebrationis, and rejected the conversion of the marriage into a civil partnership perceiving it to be both practically and symbolically a lesser substitute. ${ }^{212}$ The Court ruled that abiding single sex relationships are in no way inferior, nor does English Law suggest that they are by according them recognition under the name of civil partnership, and that marriage was an "age-old institution" which, he suggested, was by "longstanding definition and acceptance" a relationship between a man and a woman. ${ }^{213}$ However, Waaldijk is of the view that:

Intimate partnership can mean different things to different people at different times. For many people it would (ideally) involve loving each other, caring for each other, living together in the same house, having sexual contact with each other, raising children together, staying together for life, and having some things in joint possession. However, none of these characteristics seems to be a universal conditio sine qua non for marriage or for other forms of intimate partnership. ${ }^{214}$

Civil partnership is a relationship between two people that is intimate in at least some of the ways mentioned. ${ }^{215}$ International law on the protection of human rights recognizes and protects the desire for and existence of intimate partnership. It does so mainly through guaranteeing rights to marriage, to family, and to private life, and through prohibitions of discrimination. ${ }^{216}$ Existing intimate partnerships can be classified as being either between partners of different sexes or between partners of the same sex. Although international human rights instruments do not contain wordings that refer explicitly to heterosexual partnership, their provisions on the rights to marriage, to family, and to privacy have traditionally often been interpreted as only covering different-sex partners. "Thus same-sex partnership has often been excluded from the protection of these rights."217

It is usually argued that giving same-sex partnerships "the status of marriage 'would alter the intrinsic nature of marriage as the union of a man and a woman.'" 218 This view derives from the fact that, among others, marriage creates legal rights and obligations that balance the needs of the couple regardless of the economic contribution (if any) they make to the relationship. Further, marriage is a form of self-definition. Changing status from single

212. Wilkinson v. Kitzinger, [2006] EWHC 2022 (Fam); [2006] H.R.L.R. 36.

213. Id. Per Judge Sir Potter.

214. Waaldijk, supra note 12 , ฯ 2.

215. Id.

216. Id. ๆ 3

217. Id.

218. Church of England Warning on Gay Marriage, supra note 91. 
to married alters one's identity fundamentally. ${ }^{219}$ Furthermore, "marriage constitutes a major, if not the ultimate, societal endorsement of lifestyles sought by the married couple." 220 Notably, the Hyde v. Hyde definition is confined to Christendom when not all people are Christians. The question today is whether the meaning of marriage should be fixed to what it meant in 1866 or if it must adapt to the constitutional guarantees of equality and non-discrimination and evolve with the society that currently represents a plurality of groups. Also, the language of Article 23 of the ICCPR does not specify that it is restricted to one man and one woman. ${ }^{221}$ In Africa and elsewhere marriage is acknowledged in many forms such as monogamous, polygamous, polyandrous, and heterosexual. As such, there seems to be no compelling justification for excluding same-sex marriages in the equation. ${ }^{222}$ Saiz has noted that: "'marriage' and 'the family' are continuously evolving concepts that apply to a diversity of arrangements across cultures and so must be interpreted broadly. Neither is defined in any international standard."223

Fellmeth argues that:

[h]omosexuals, by the nature of their sexual orientation, are also typically in a relationship with someone of their own sex and would only wish to marry someone of their own sex. To deny homosexuals the right to same-sex marriage is equally an "effective bar on any exercise" of their right to marry. ${ }^{224}$

This is a blatant infringement of the very essence of their right to marry. ${ }^{225}$ When the state regulates or oppresses the "right to choose who to love and with whom to live," that trumps the private choices one ought to make about with whom to share one's "most intimate moments." 226 In Perry v. Schwarzenegger, Judge Walker stated that:

The right to marry has been historically and remains the right to choose a spouse and, with mutual consent, join together and form a household. Race and gender restrictions shaped marriage during eras of race and gender inequality, but such restrictions were never part of the historical core of the institution of marriage. Today, gender is not relevant to the state in determining spouses' obligations to each other and to their dependents. Relative gender composition aside, samesex couples are situated identically to opposite-sex couples in terms of their ability to perform the rights and obligations of marriage under California law. Gender no longer forms an essential part of marriage; marriage under law is a union of equals. 227

219. Fellmeth, supra note 18 , at 848-49.

220. Id.

221. ICCPR, supra note 163, art. 23.

222. Mutua, supra note 2 , at 460 .

223. Saiz, supra note 3 , at 9 .

224. Fellmeth, supra note 18 , at 852.

225. Goodwin v. United Kingdom, App. No. 28957/95, 22 Eur. H.R. Rep. 123, ๆ 101 (2002).

226. Amnesty Int'L, Love, Hate And the LaW, supra note 14 , at 7.

227. Perry, supra note $121,113$. 
The question in Joslin v. New Zealand, inter alia, was whether a samesex couple can derive a right to marry from international human rights law. The HRC held that because of the words "men and women" in the wording of the right to marry in Article 23(2) of the ICCPR, the exclusion of same-sex couples from marriage violated the provision. ${ }^{228}$ This means that this right "must in all circumstances be limited to marriage between two persons of the opposite sex." ${ }^{229}$ The HRC justified its decision stating that Article 23(2) of the ICCPR establishes the "right of men and women of marriageable age to marry and to found a family." ${ }^{\prime 230}$ The Court interpreted Article 23(2) to establish the right of men of marriageable age to marry women of marriageable age, and vice versa. ${ }^{231}$ The Committee contrasted the ICCPR's use of the terms "'every human being,' 'everyone,' and 'all persons" in other provisions of the ICCPR with Article 26's use of the term "men and women" in the ICCPR. ${ }^{232}$

In Minister of Home Affairs v. Fourie, the South African Constitutional Court extended the common-law definition of marriage to include same-sex spouses. The court ruled unanimously that the common-law definition of marriage was invalid because it unconstitutionally discriminated on the basis of sexual orientation, and that the definition should be extended to read that marriage "is the voluntary union of two persons to the exclusion of all others while it lasts." ${ }^{233}$ When the constitutionality of the Marriage Act was questioned in a later case, justices agreed unanimously that the common-law definition of marriage and the marriage formula in the Marriage Act, to the extent that they excluded same-sex partners from marriage, were unfairly discriminatory, unjustifiable, and therefore unconstitutional and invalid. ${ }^{234}$

What same-sex couples demand is legal recognition of their relationship on the same footing as opposite sex couples. For these reasons, governments must ensure that marriages receive legal recognition without discrimination. Marriage should not be the exclusive privilege of different-sex couples; samesex couples that fulfill the requirements of a valid marriage should be legally recognized with the concomitant legal consequences. Regardless of the nomenclature that is given to same-sex marriages-for example, civil unions or civil partnerships - they should not be created as a means to deny samesex couples equal rights. The South African Civil Union Act is an instructive model in this regard. ${ }^{235}$ The Civil Union Act provides for opposite-sex and

228. Joslin, supra note 160; see also Schalk, supra note 43, ๆ 61.

229. Schalk, supra note 43, ๆ 61.

230. ICCPR, supra note 163, art. 23; see also Joslin, supra note 160, ๆ 8(2).

231. Joslin, supra note 160 , 9 8.2.

232. Fellmeth, supra note 18 , at 863.

233. Fourie, supra note 174.

234. Republic of South Africa, Civil Union Act, Government Gazette, 30 Nov. 2006, at. 10.

235. Id. 
same sex civil marriages, religious marriages, and civil partnerships. Couples marrying under the Civil Union Act may chose whether their union should be registered a as a marriage or a civil partnership. In either case, the legal consequences are the same as those under the Marriage Act save as the context may require.236 The prohibited degrees of affinity and consanguinity that apply under the marriage Act also apply to the Civil Union Act. $^{237}$

\section{LOCATING SEXUALITY RIGHTS}

Whether sexuality rights should be dealt with as a human right is an issue that remains unresolved. The answer begins with a consideration of the values in which human rights are grounded. Human rights are grounded primarily in personhood, from which most conventional human rights are derived. ${ }^{238}$ For example, one has the right to life because of personhood; that is, by virtue of being human. "The many dimensions of human sexualityphysical, mental, spiritual, social, associational-intersect with a multiplicity of rights." ${ }^{239}$ Saiz, quoting Hunt, has stated that:

Affirming that "sexuality is a characteristic of all human beings [and] a fundamental aspect of an individual's identity," he concludes that "the correct understanding of fundamental human rights principles, as well as existing human rights norms, leads ineluctably to the recognition of sexual rights as human rights. Sexual rights include the right of all persons to express their sexual orientation, with due regard for the well-being and rights of others, without fear of persecution, denial of liberty or social interference." 240

Therefore, it is correct to see sexuality rights-insofar as they border on the prohibition of discrimination-as constitutional rights. The principles underpinning sexuality rights include autonomy, empowerment, bodily integrity, and respect for sexual and family diversity. ${ }^{241}$ According to Alexy:

Undoubtedly, rights become constitutional because of their perceived substantive significance as expressions of an underlying political morality. But substantive significance alone does not secure legal recognition. Most obviously, certain

236. Id. at. 6 .

237. See, Republic of South Africa, Recognition of Customary Marriages Act, Government Gazette, 2 Dec. 1998, at. 4.

238. James Griffin, On Human Rights 33 (2008).

239. Saiz, supra note 3 , at 20.

240. Id. at 21; Paul Hunt, Report of the Special Rapporteur on the Right to Health, U.N. Office of the High Comm'r for Hum. Rts., I 54, U.N. Doc. E/CN.4/2004/49 (16 Feb. 2004).

241. Saiz, supra note 3, at 20; Rosalind Pollack Petchesky, Sexual Rights: Inventing a Concept, Mapping an International Practice, in Sexual Identities, Queer Politics 118 (Mark Blasius ed., 2001). 
rights are constitutional because they have a status which is higher in hierarchy of legal norms than ordinary legal rights. This in turn gives rise to an expectation that they have relevance to the whole of law. ${ }^{242}$

Thus, constitutional rights are not "absolute" jurisdictional limits, as they tend to give rise to procedural obstacles to the legislative and executive action that "departs from the presumptions of political morality expressed in the constitutional rights catalogue." ${ }^{243}$ Certain human rights, such as the right to equality and non-discrimination, are so basic to the survival of democracy and democratic institutions that they deserve some special treatment. ${ }^{244}$ The concept of equality of peoples and non-discrimination is fundamental to the concept of human rights. ${ }^{245}$ In fact the whole question of human rights would be meaningless without equal protection and non-discrimination. ${ }^{246}$ Indeed, sexuality, including sexual orientation, is recognized as an analogous ground of non-discrimination under the phrase "or other status" or even "sex" as determined by the HRC.

Sexuality rights should be distinguished from the right to engage in sexual activity, which is the "equal right of all [adult] persons to consensual sexual activity in private, free of discrimination, coercion, violence and threats to health, and the right to determine what relation such conduct has to reproduction." ${ }^{247}$ "Sexual rights include the right of all persons to express their sexual orientation, with due regard for the well-being and rights of others, without fear of persecution, denial of liberty or social interference ${ }^{\prime 248}$ Sexuality rights embody human rights that are already recognized in national laws and international human rights law. They include:

the right of all persons, free of coercion, discrimination and violence, to: (1) the highest attainable standard of sexual health, including access to sexual and reproductive health care services; (2) seek, receive and impart information related to sexuality; (3) sexuality education; (4) respect for bodily integrity; (5) choose their partner; (6) decide to be sexually active or not; (7) consensual sexual relations; (8) consensual marriage; (9) decide whether or not, and when, to have children; and (10) pursue a satisfying, safe and pleasurable sexual life. The responsible exercise of human rights requires that all persons respect the rights of others. ${ }^{249}$

242. AleXY, supra note 130 , at xix.

243. Id. at xxi.

244. See, e.g., Constitution of the Republic of Malawi, § 20, available at http://www.chr. up.ac.za/undp/domestic/docs/c_Malawi.pdf.

245. See generally Marc Galanter, Competing Equalities: Law and the Backward Classes in India (1984).

246. Mutua, supra note 2, at 452 .

247. Sexuality and Human Rights, supra note 4, at 23.

248. Paul Hunt, supra note 240.

249. WHO, Gender and Human Rights, available at http://www.who.int/reproductivehealth/ topics/gender_rights/sexual_health/en/. 
The discourse of sexuality rights offers fresh conceptual and strategic tools for framing sexuality from various perspectives including women's rights, population, and others. The concept of sexuality rights helps to address the intersections between sexual orientation discrimination and other sexuality issues—such as restrictions on all sexual expression outside mar-riage or abuses against sex workers - and to identify root causes of different forms of oppression. ${ }^{250}$ The concept of sexuality rights also offers strategic possibilities for a coherent human rights doctrine to promote and defend the specific rights of LGBT people. ${ }^{251}$ Sexuality rights make a positive claim to universality since they relate to an element of the self common to all human beings, which is their sexuality.

"The concept [of sexuality rights] therefore avoids the complex task of identifying a fixed subcategory of humanity to whom these rights apply. It proposes an affirmative vision of sexuality as a fundamental aspect of being human, as central to the full development of human health and personality as one's freedom of conscience and physical integrity. Sexuality rights offer enormous transformational potential, not just for society's 'sexual minorities' but for its 'sexual majorities' as well." ${ }^{252}$ Making a case for sexuality rights may be more compelling considering that every human being has a sexuality which is immutable and attributable to one's inner self. ${ }^{253}$

\section{CONCLUSION}

Article 2 of the Banjul Charter prohibits any form of discrimination, which arguably includes discrimination on the basis of one's sexuality. ${ }^{254}$ In terms of Article 3 of the Banjul Charter, every individual, including LGBT individuals, is equal before the law and entitled to equal protection of the law. It follows that discrimination against LGBT individuals is contrary to the dictates of the Banjul Charter. Criminalization of homosexuality is not only homophobic but also infringes upon the requirement of equality and equal protection under the law in terms of Article 3 of the Banjul Charter. Criminalization of unconventional or queer sexual acts does not prevent the proscribed sexual acts; it stigmatizes LGBT people as "deviants" who are likely to corrupt others. It also encourages the dehumanization of LGBT people by effectively making that aspect of their identity illegal and even punishable by death. ${ }^{255}$ This leads to the issue of whether one can extort moral values with imprisonment. Criminalizing queer sexual acts creates

250. Id.

251. Saiz, supra note 3, at 20.

252. Id.

253. But see id. at 18, n. 90; Anthony Giddens, Runaway World: How Globalization is Reshaping our Lives, at ch. 3-4 (2000).

254. Banjul Charter, supra note 5.

255. Report of the UN Special Rapporteur on Extrajudicial, Summary or Arbitrary Executions, Ms. Asma Jahangir, I 50, U.N. Doc. E/CN.4/2001/9, (11 Jan. 2001). 
moral standards by fear not conviction. ${ }^{256}$ Therefore, one cannot convince those practicing unconventional sexuality to be conventional where such activities are criminal, as they are invariably going to be surreptitious.

The need to limit entitlement in order to ensure respect for the rights of others is a core value of human rights. It is, therefore, understandable that the state may intervene to prevent harm to the rights of others and public good. ${ }^{257}$ What is not understandable is why the state should intervene in harmless and victimless acts of queer sexuality at the expense of other rights relating to equality, non-discrimination, expression, and the right to marry, among others. ${ }^{258}$ The fact that the majority dislikes a particular practice-or considers it immoral, exotic, etc - is not sufficient reason for criminalizing unconventional sexuality. ${ }^{259}$ Article 19 of the Banjul Charter is clear on this: "All peoples shall be equal; they shall enjoy the same respect and shall have the same rights. Nothing shall justify the domination of a people by another." Prohibition or limitation of freedom or liberty requires a compelling justification and a high burden for the state to discharge.60

Governments have invoked justifications such as "cultural sovereignty," "protection of public morals," "religious sanctity," and "traditional values" as a justification for criminalizing queer sexuality. However, aside from procreation, love, choice, commitment, and privacy play a pivotal role in the marital relationship in contemporary societies. A direct way of encouraging procreation is not to criminalize same sex relationships but to reward pro-creation with subsidies or benefits to those able and inclined to procreate. In any event, queer sexuality does not preclude procreation, as there is a possibility of artificial insemination. Guiding the morality of individuals is not the responsibility of the state but religious leadership.

Mere decriminalization of homophobic laws is not a panacea, but it is a key step towards respecting, protecting, and fulfilling the human rights of LGBT and recognition of same-sex relationships. However, decriminalization of homophobic laws does not amount to state recognition of homosexuality. ${ }^{261}$ Although the recognition of same-sex marriage is a step towards ending discrimination on grounds of sexuality, legalization does not end discrimination, either by public officials or private individuals. ${ }^{262}$ States should ensure that sexuality rights are respected both in policy and practice. States should

256. Sonke, supra note 87 .

257. See UDHR, supra note 57, art. 29(2).

258. See General Comment No. 18, Non-Discrimination, adopted 10 Nov. 1989, U.N. GAOR, Hum. Rts. Comm., 37th Sess., I 13, U.N. Doc. CCPR/C/21/Rev.1/Add.1 (1989); see also ICCPR, supra note 163, arts. 18, 19, 21, 22; Sexuality and Human Rights, supra note 4 , at 40.

259. Lawrence, supra note 41, at 17; Toonen, supra note 158, 9 8.6; Sexuality and Human Rights, supra note 4 , at 41 .

260. Mutua, supra note 2, at 454.

261. Amnesty Int'L, Love, Hate and the Law, supra note 14 , at 38.

262. HRW, A Decade on, Progress on Same-Sex Marriages: But Even Where Laws Changed, Unyielding Bias Persists Based on Sexual Orientation (2011), available at http://www. hrw.org/news/2011/03/14/decade-progress-same-sex-marriages. 
therefore "take all necessary legislative, administrative and other measures to eliminate and prohibit discrimination on the basis of sexual orientation, assumptions as to consensual same-sex practices and gender identity in public and private employment; including in relation to vocational training, recruitment, promotion, dismissal, conditions of employment and remuneration."263

"Current theory and practice of sexuality" is not limited to the "rigid binary classification [of] the norm (heterosexuality) and the exception (homosexuality)."264 Transgender people challenge the binary way of thinking that there are two and only two genders and should not be made to pay for that queer sexuality. ${ }^{265}$ Therefore, the debate should first break out of the binaries of heterosexuality and homosexuality and focus on the big picture of sexuality. This reasoning is derived from the legal regime of elimination of racism, which does not proscribe discrimination against blacks or whites but rather the broader picture of race, color, or such status. In this way, to achieve equality, laws should prohibit homophobia and not homosexuality.

Instead of polarizing the issue of decriminalization of homophobic laws and non-discrimination of LGBT people, the sexuality rights discourse may be an appropriate approach to convince conservatives and bigots. This is because sexuality rights make an affirmative claim to universality, since they relate to an element of the self that is common and immutable to all humans, i.e., sexuality. It is correct to take into account the differences in each other's religious beliefs and cultural values regarding sexuality. Certainly, the values of the West are not the same as those of the rest. Africans, for instance, have a different culture based on much more fundamental religious beliefs and cultural values. What is needed is understanding, respect, and constructive dialogue. The common denominator is respect for the human rights of all, including sexuality rights, as they are personal and fundamental to individuals and their identities.

Africans have been vocal advocates for the protection of equal rights and non-discrimination; it will be hypocritical if they pick and choose classes of people to be protected. As Mutua has argued, "homophobia is an irrational fear that is used to deny basic rights and which society has an obligation to overcome." 266 Article 28 of the Banjul Charter imposes a duty on individuals to respect one another without discrimination, "and to maintain relations aimed at promoting, safeguarding and reinforcing mutual respect and tolerance." This proscribes homophobia and requires respecting and tolerating differences based on sexuality, including sexual orientation and sexual identity. Given the prevalence of homophobia in Africa, elimination of homophobia within the educational system is also crucial to ending

263. AMnESTY INT'L, supra note 14, at 43.

264. Stychin, supra note 24, at 223.

265. Sexuality and Human Rights, supra note 4, at 39, 44.

266. Mutua, supra note 2, at 452 . 
discrimination on the grounds of sexuality and realization of the rights of all human beings, "born free and equal in dignity." ${ }^{267}$ What this means is that people should not be discriminated or prosecuted because of who they are or who they love.

267. The Yogyakarta Principles, supra note 35. 